\title{
Analytical Results of MOX Colemanite Concrete Sample Poured July 25, 2012 - Cured 28 Days
}

D.R. Best

A.D. Cozzi

M.M. Reigel

September 2012

Savannah River National Laboratory

Savannah River Nuclear Solutions, LLC

Aiken, SC 29808

Prepared for the U.S. Department of Energy under contract number DE-AC09-08SR22470. 
SRNL-STI-2012-00543

Revision 0

\section{DISCLAIMER}

This work was prepared under an agreement with and funded by the U.S. Government. Neither the U.S. Government or its employees, nor any of its contractors, subcontractors or their employees, makes any express or implied:

1. warranty or assumes any legal liability for the accuracy, completeness, or for the use or results of such use of any information, product, or process disclosed; or

2. representation that such use or results of such use would not infringe privately owned rights; or

3. endorsement or recommendation of any specifically identified commercial product, process, or service.

Any views and opinions of authors expressed in this work do not necessarily state or reflect those of the United States Government, or its contractors, or subcontractors.

\section{Printed in the United States of America}

Prepared for

U.S. Department of Energy 
SRNL-STI-2012-00543

Revision 0

Keywords: $M O X$ Colemanite

Concrete

Retention: Permanent

\section{Analytical Results of MOX Colemanite Concrete Sample Poured July 25, 2012 - Cured 28 Days}

D.R. Best

A.D. Cozzi

M.M. Reigel

September 2012

Savannah River National Laboratory

Savannah River Nuclear Solutions, LLC

Aiken, SC 29808

Prepared for the U.S. Department of Energy under contract number DE-AC09-08SR22470. 


\section{REVIEWS AND APPROVALS}

AUTHORS:

D.R. Best, Engineering Process Development

Date

A.D. Cozzi, Engineering Process Development

Date

M.M. Reigel, Engineering Process Development

Date

TECHNICAL REVIEW:

B.R. Pickenheim, Engineering Process Development

Date

APPROVAL:

K.M. Fox, Manager

Date

Engineering Process Development

S.L. Marra, Manager

Date

E\&CPT Research Programs 


\section{EXECUTIVE SUMMARY}

The Mixed Oxide Fuel Fabrication Facility (MFFF) will use Colemanite bearing concrete neutron absorber panels credited with attenuating neutron flux in the criticality design analyses and shielding operators from radiation. The Savannah River National Laboratory is tasked with measuring the total density, partial hydrogen density, and partial boron density of the colemanite concrete.

Samples 8.1.2, 8.2.2, 8.3.2, and 8.4.2 were received on 8/1/2012 and analyzed after curing for 28 days. The average total density measured by the ASTM method C 642 was $2.09 \mathrm{~g} / \mathrm{cm}^{3}$, within the lower bound of $1.88 \mathrm{~g} / \mathrm{cm}^{3}$. The average partial hydrogen density was $7.48 \mathrm{E}-02 \mathrm{~g} / \mathrm{cm}^{3}$ as measured using method ASTM E 1311 and met the lower bound of $6.04 \mathrm{E}-02 \mathrm{~g} / \mathrm{cm}^{3}$. The average measured partial boron density was $1.71 \mathrm{E}-01 \mathrm{~g} / \mathrm{cm}^{3}$ which met the lower bound of $1.65 \mathrm{E}-01$ $\mathrm{g} / \mathrm{cm}^{3}$ measured by the ASTM C 1301 method. 


\section{TABLE OF CONTENTS}

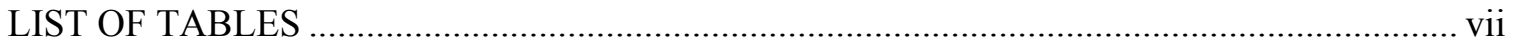

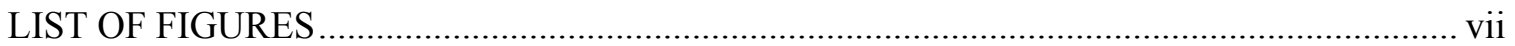

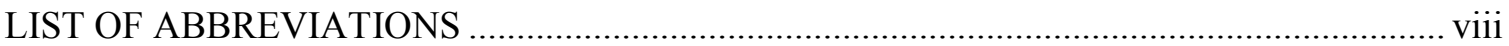

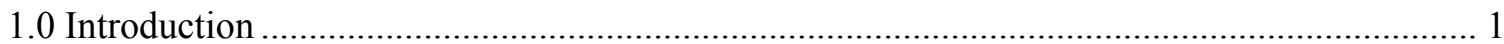

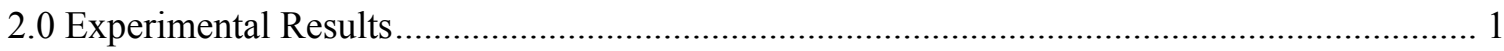

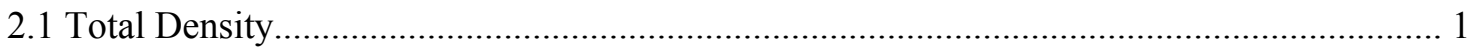

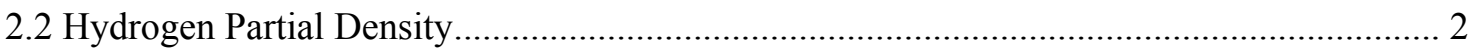

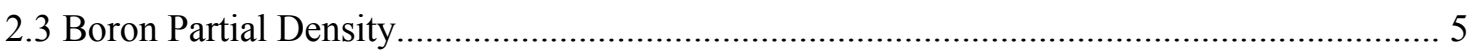

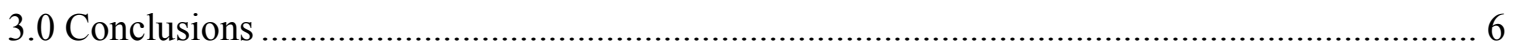

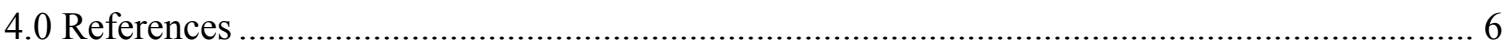




\section{LIST OF TABLES}

Table 1. Acceptable Material Neutron Absorber Characteristics................................................. 1

Table 2. Mass Measurements of Subsamples After Each Treatment............................................ 1

Table 3. Calculated Results of Equations 1-7 for the Colemanite Concrete. ................................. 2

Table 4. Mass change Over Temperature Ranges for Samples made on July 25, 2012 ................ 5

Table 5. Boron Results of Colemanite Concrete Analyzed using ASTM C 1301........................ 6

Table 6. Lower Bounds and Average Measured Values for the Total Density, Hydrogen Partial Density, and Boron Partial Density for the Colemanite Concrete Samples Received 01

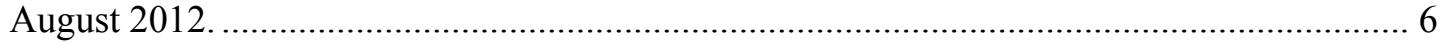

\section{LIST OF FIGURES}

Figure 1. TGA Curves Showing Mass Loss of Samples Heated at $5{ }^{\circ} \mathrm{C} / \mathrm{min}$ Under Flowing Nitrogen. 


\section{LIST OF ABBREVIATIONS}

$\begin{array}{ll}\text { DSC } & \text { Differential Scanning Calorimetry } \\ \text { ICP } & \text { Inductively Coupled Plasma } \\ \text { MFFF } & \text { Mixed Oxide Fuel Fabrication Facility } \\ \text { OES } & \text { Optical Emission Spectrometer } \\ \text { PSAL } & \text { Process Science Analytical Laboratory } \\ \text { SRNL } & \text { Savannah River National Laboratory } \\ \text { TGA } & \text { Thermal Gravimetric Analysis }\end{array}$




\subsection{Introduction}

The Mixed Oxide Fuel Fabrication Facility (MFFF) will use Colemanite bearing concrete neutron absorber panels credited with attenuating neutron flux in the criticality design analyses and shielding the operator from radiation ${ }^{1}$. Table 1 is an excerpt from Table 2.1.2.3 in Reference 1.

Table 1. Acceptable Material Neutron Absorber Characteristics.

\begin{tabular}{|c|c|c|c|}
\hline Material Type & $\begin{array}{l}\text { Total Density Lower } \\
\text { Bound }\left(\mathrm{g} / \mathrm{cm}^{3}\right)\end{array}$ & $\begin{array}{c}\text { Hydrogen Partial Density } \\
\text { Lower Bound }\left(\mathrm{g} / \mathrm{cm}^{3}\right)\end{array}$ & $\begin{array}{l}\text { Boron Partial Density } \\
\text { Lower Bound }\left(\mathrm{g} / \mathrm{cm}^{3}\right)\end{array}$ \\
\hline $\begin{array}{l}\text { Borated Concrete } \\
\text { (Colemanite) }\end{array}$ & 1.88 & $6.04 \mathrm{E}-02$ & $1.65 \mathrm{E}-01$ \\
\hline
\end{tabular}

The Savannah River National Laboratory is tasked with measuring the properties of the colemanite concrete identified in Table $1^{2}$.

\subsection{Experimental Results}

Samples 8.1.2, 8.2.2, 8.3.2, and 8.4.2 were received on 8/1/2012. The samples consisted of four 2 -inch cubes cast on $7 / 25 / 2012$. The samples were analyzed after 28 days of curing. A duplicate set of samples were analyzed after 7 days of curing ${ }^{3}$.

\subsection{Total Density}

The total density of the sample was determined by the ASTM method for density in hardened concrete ${ }^{4}$. Subsamples of each of the cubes were crushed for the density determination.

The ASTM method was followed with the exception of sample size. Section 4.1 of the ASTM procedure specifies a sample size of approximately 800 grams. As each subsample weighed between 133 to 138 grams, a reduced sample size was used. Duplicate subsamples of each cube were analyzed. Mass measurements were taken after each treatment with the masses being designated A through $\mathrm{D}$, where;

$\mathrm{A}=$ mass of oven-dried sample in air between 100 to $110^{\circ} \mathrm{C}, \mathrm{g}$

$\mathrm{B}=$ mass of surface-dry sample in air after immersion, $\mathrm{g}$

$\mathrm{C}=$ mass of surface-dry sample in air after immersion and boiling, $\mathrm{g}$

$\mathrm{D}=$ apparent mass of sample in water after immersion and boiling, g, Table 2 .

Table 2. Mass Measurements of Subsamples After Each Treatment.

\begin{tabular}{||c|c|c|c|c||}
\hline Subsample & $\mathbf{A ~ ( g )}$ & $\mathbf{B}$ (g) & $\mathbf{C} \mathbf{( g )}$ & $\mathbf{D}(\mathbf{g})$ \\
\hline Treatment & dry & saturated & boil/saturated & suspended \\
\hline Date & $29-$ Aug-12 & 4-Sep-12 & 5-Sep-12 & 5-Sep-12 \\
\hline $8.1 .2 \mathrm{a}$ & 20.778 & 23.565 & 23.758 & 12.488 \\
\hline $8.1 .2 \mathrm{~b}$ & 13.621 & 15.481 & 15.577 & 8.169 \\
\hline $8.2 .2 \mathrm{a}$ & 12.398 & 14.200 & 14.266 & 7.418 \\
\hline $8.2 .2 \mathrm{~b}$ & 27.060 & 30.894 & 31.263 & 16.373 \\
\hline $8.3 .2 \mathrm{a}$ & 9.834 & 11.231 & 11.199 & 5.840 \\
\hline $8.3 .2 \mathrm{~b}$ & 16.079 & 18.323 & 18.306 & 9.630 \\
\hline $8.4 .2 \mathrm{a}$ & 10.849 & 12.526 & 12.441 & 6.463 \\
\hline $8.4 .2 \mathrm{~b}$ & 17.609 & 20.213 & 20.242 & 10.595 \\
\hline
\end{tabular}

Using the calculations in the ASTM method, the following properties were calculated:

Absorption after immersion, $\%=\frac{B-A}{A} \times 100$, 
Absorption after immersion and boiling, $\%=\frac{C-A}{A} \times 100$,

Bulk density, dry $=\frac{A}{C-D} \times \rho$,

Bulk density after immersion $=\frac{B}{C-D} \times \rho$,

Bulk density after immersion and boiling $=\frac{C}{C-D} \times \rho$,

Apparent density $=\frac{A}{A-D} \times \rho$,

Volume of permeable pore space $=\frac{C-A}{C-D} \times 100$

The density used in these calculations is that of water, $\left(\sim 1 \mathrm{~g} / \mathrm{cm}^{3}\right)$. The results of the calculations performed with Equations 1-7 are tabulated and averaged in Table 3.

Table 3. Calculated Results of Equations 1-7 for the Colemanite Concrete.

\begin{tabular}{|c|c|c|c|c|c|c|c|}
\hline $\begin{array}{c}\text { Sample } \\
\text { ID }\end{array}$ & $\begin{array}{c}\text { Absorption } \\
\text { Eq (1) } \\
(\%)\end{array}$ & $\begin{array}{c}\text { Absorption } \\
\text { Eq (2) } \\
(\%)\end{array}$ & $\begin{array}{c}\text { Bulk } \\
\text { Density } \\
\text { Eq (3) } \\
\left(\mathrm{g} / \mathrm{cm}^{3}\right) \\
\end{array}$ & $\begin{array}{c}\text { Bulk } \\
\text { Density } \\
\text { Eq (4) } \\
\left(\mathrm{g} / \mathrm{cm}^{3}\right) \\
\end{array}$ & $\begin{array}{c}\text { Bulk } \\
\text { Density } \\
\text { Eq (5) } \\
\left(\mathrm{g} / \mathrm{cm}^{3}\right) \\
\end{array}$ & $\begin{array}{l}\text { Apparent } \\
\text { Density } \\
\text { Eq (6) } \\
\left(\mathrm{g} / \mathrm{cm}^{3}\right) \\
\end{array}$ & $\begin{array}{l}\text { Permeable } \\
\text { void \% } \\
\text { Eq (7) }\end{array}$ \\
\hline $8.1 .2 \mathrm{a}$ & 13.41 & 14.34 & 1.84 & 2.09 & 2.11 & 2.51 & 26.44 \\
\hline $8.1 .2 \mathrm{~b}$ & 13.66 & 14.36 & 1.84 & 2.09 & 2.10 & 2.50 & 26.40 \\
\hline 8.1.2 Avg & 13.53 & 14.35 & 1.84 & 2.09 & 2.11 & 2.50 & 26.42 \\
\hline $8.2 .2 \mathrm{a}$ & 14.53 & 15.07 & 1.81 & 2.07 & 2.08 & 2.49 & 27.28 \\
\hline $8.2 .2 \mathrm{~b}$ & 14.17 & 15.53 & 1.82 & 2.07 & 2.10 & 2.53 & 28.23 \\
\hline 8.2.2 Avg & 14.35 & 15.30 & 1.81 & 2.07 & 2.09 & 2.51 & 27.75 \\
\hline $8.3 .2 \mathrm{a}$ & 14.21 & 13.88 & 1.84 & 2.10 & 2.09 & 2.46 & 25.47 \\
\hline $8.3 .2 \mathrm{~b}$ & 13.96 & 13.85 & 1.85 & 2.11 & 2.11 & 2.49 & 25.67 \\
\hline 8.3.2 Avg & 14.08 & 13.87 & 1.84 & 2.10 & 2.10 & 2.48 & 25.57 \\
\hline $8.4 .2 \mathrm{a}$ & 15.46 & 14.67 & 1.81 & 2.10 & 2.08 & 2.47 & 26.63 \\
\hline $8.4 .2 \mathrm{~b}$ & 14.79 & 14.95 & 1.83 & 2.10 & 2.10 & 2.51 & 27.29 \\
\hline $8.4 .2 \mathrm{Avg}$ & 15.12 & 14.81 & 1.82 & 2.10 & 2.09 & 2.49 & 26.96 \\
\hline
\end{tabular}

Equations (4) and (5) are the most appropriate to represent the density of the Colemanite concrete as the concrete is saturated with water during placement. The average density of the colemanite concrete measured using ASTM C 642 equation (4) was $2.09 \mathrm{~g} / \mathrm{cm}^{3}$.

\subsection{Hydrogen Partial Density}

The hydrogen partial density in the colemanite concrete was determined using the ASTM method for determining volatile content using thermogravimetric analysis ${ }^{5}$. ASTM E 1131-08 defines highly volatile matter as components that will volatilize below $200^{\circ} \mathrm{C}$ and medium volatile matter as components that will degrade or volatilize in the range of $200-750{ }^{\circ} \mathrm{C}$. In an evaluation of the thermal decomposition of colemanite, Waclawska et al. determined that the release of water from colemanite was complete at $600{ }^{\circ} \mathrm{C}$ and that melting and crystallization of a calcium borate phase occurred above $650{ }^{\circ} \mathrm{C}^{6}$. A Netzsch STA 409 Luxx, which couples Differential Scanning Calorimetry (DSC) with Thermal Gravimetric Analysis (TGA), was used for TGA of the colemanite concrete samples. After loading the sample, the chamber was purged with nitrogen at $60 \mathrm{ml} / \mathrm{min}$ prior to heating. Triplicate samples from 8.1.2, 8.2.2, 8.3.2, and 8.4.2 were heated at $5{ }^{\circ} \mathrm{C} / \mathrm{min}$ up to $650{ }^{\circ} \mathrm{C}$ in a flowing nitrogen atmosphere of $60 \mathrm{ml} / \mathrm{min}$, Figure 1 . The initial mass loss is associated with the free water from the mix. The second mass loss beginning below $400{ }^{\circ} \mathrm{C}$ 
is due to the thermal decomposition of the colemanite. Table 4 is the mass change for the four samples.
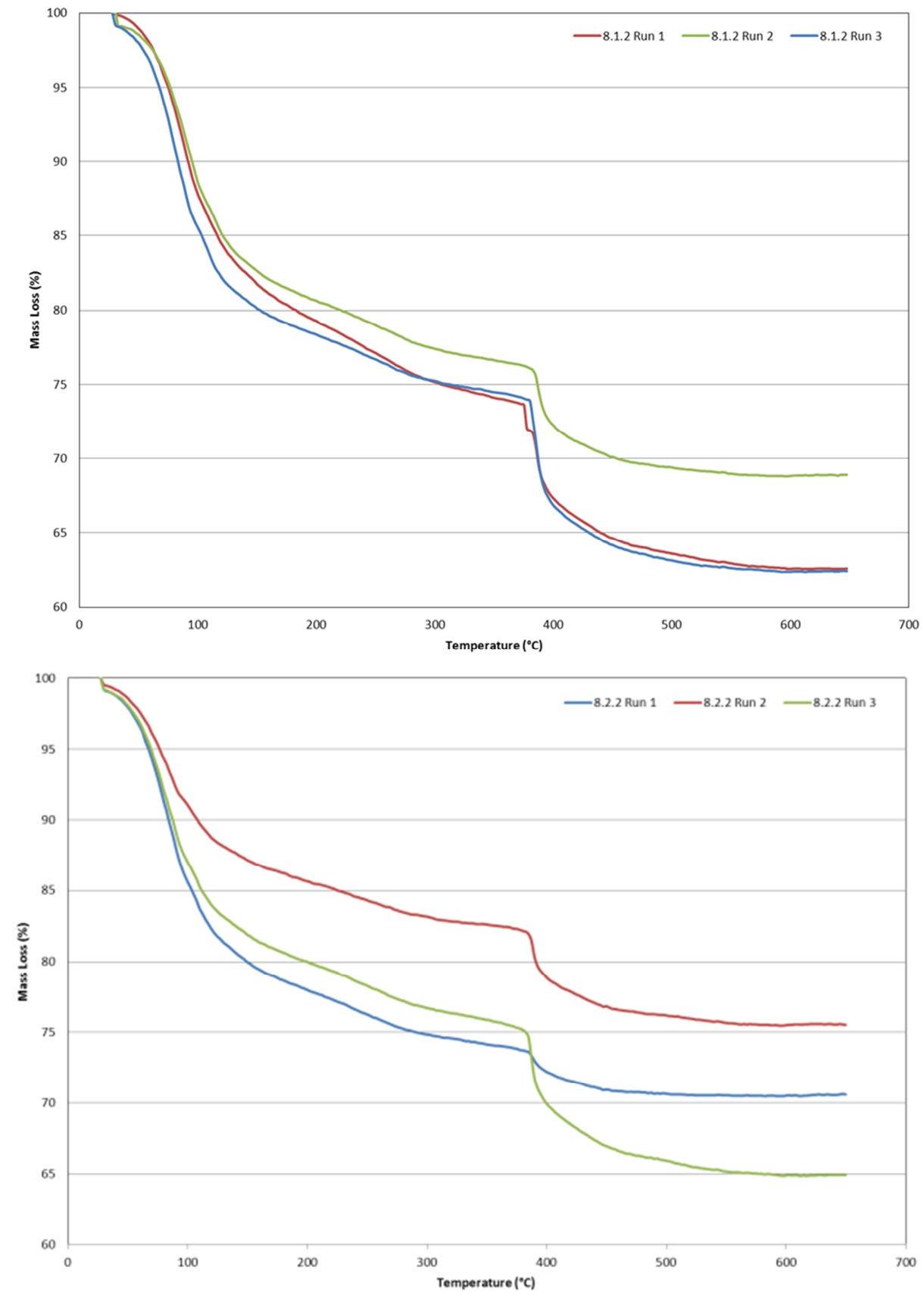

Figure 1. TGA Curves Showing Mass Loss of Samples Heated at $5{ }^{\circ} \mathrm{C} / \mathrm{min}$ Under Flowing Nitrogen--continued. 
SRNL-STI-2012-00543

Revision 0
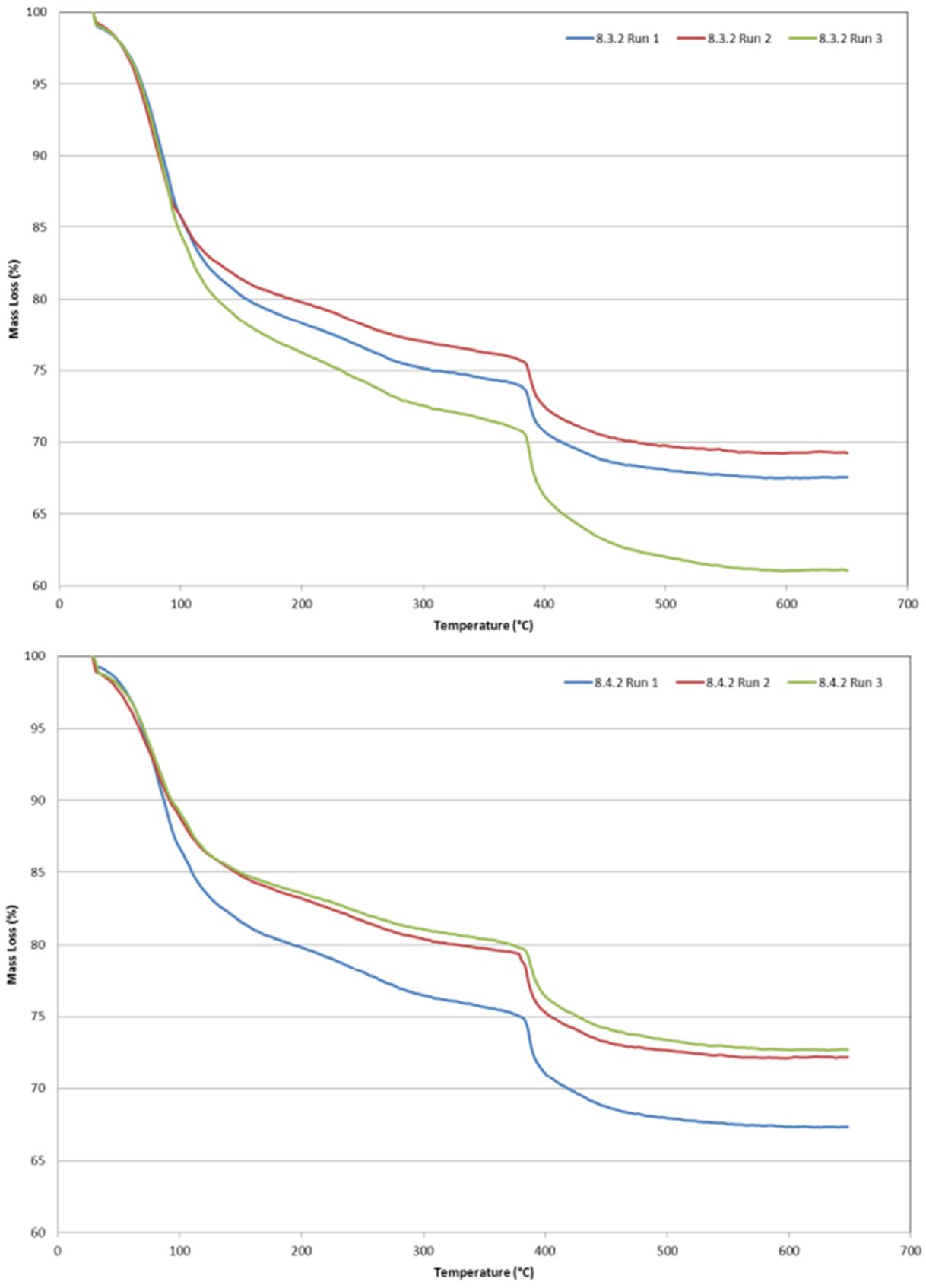

Figure 1. TGA Curves Showing Mass Loss of Samples Heated at $5{ }^{\circ} \mathrm{C} / \mathrm{min}$ Under Flowing Nitrogen. 
SRNL-STI-2012-00543

Revision 0

Table 4. Mass change Over Temperature Ranges for Samples made on July 25, 2012.

\begin{tabular}{|c|c|c|c|c|c|c|}
\hline $\begin{array}{c}\text { Sample } \\
\text { ID }\end{array}$ & Run \# & $\begin{array}{c}\text { Mass Loss } \\
(\%) \\
25-175^{\circ} \mathrm{C}\end{array}$ & $\begin{array}{c}\text { Mass Loss } \\
(\%) \\
300-600{ }^{\circ} \mathrm{C}\end{array}$ & $\begin{array}{c}\text { Total Mass } \\
\text { Loss (\%) }\end{array}$ & $\begin{array}{c}\text { Average } \\
\text { Mass Loss } \\
(\%)\end{array}$ & $\begin{array}{c}\text { Hydrogen } \\
\text { Partial Density } \\
\left(\mathrm{g} / \mathrm{cm}^{3}\right)\end{array}$ \\
\hline \multirow{3}{*}{8.1 .2} & 1 & 19.80 & 12.57 & 37.65 & \multirow{3}{*}{35.32} & \multirow{3}{*}{ 8.26E-02 } \\
\hline & 2 & 18.53 & 8.50 & 31.13 & & \\
\hline & 3 & 20.40 & 12.85 & 37.17 & & \\
\hline \multirow{3}{*}{8.2 .2} & 1 & 20.81 & 4.26 & 29.06 & \multirow{3}{*}{29.55} & \multirow{3}{*}{$6.86 \mathrm{E}-02$} \\
\hline & 2 & 13.64 & 7.64 & 24.47 & & \\
\hline & 3 & 19.22 & 11.81 & 35.11 & & \\
\hline \multirow{3}{*}{8.3 .2} & 1 & 20.84 & 7.61 & 32.45 & \multirow{3}{*}{33.96} & \multirow{3}{*}{ 7.99E-02 } \\
\hline & 2 & 19.22 & 7.79 & 30.45 & & \\
\hline & 3 & 22.81 & 11.53 & 38.97 & & \\
\hline \multirow{3}{*}{8.4 .2} & 1 & 19.25 & 9.14 & 32.47 & \multirow{3}{*}{29.04} & \multirow{3}{*}{$6.81 \mathrm{E}-02$} \\
\hline & 2 & 15.58 & 8.23 & 27.32 & & \\
\hline & 3 & 15.81 & 8.33 & 27.33 & & \\
\hline
\end{tabular}

Attributing the weight loss in Table 4 to water results in an average of $31.97 \mathrm{wt} \%$ water, and using a measured colemanite concrete density from Table 3, the average partial hydrogen density is calculated to be $7.48 \mathrm{E}-02 \mathrm{~g} / \mathrm{cm}^{3}$. For example, the hydrogen density of sample 8.1 .1 in Reference 3 is calculated using the equations:

Moles $\mathrm{H}_{2} \mathrm{O}$ in $100 \mathrm{~g}$ concrete $=\frac{\text { mass fraction } \mathrm{H}_{2} \mathrm{O}}{\mathrm{MW} \mathrm{H}_{2} \mathrm{O}}=\frac{31.41 \frac{\mathrm{g} \mathrm{H}_{2} \mathrm{O}}{\mathrm{gconcrete}}}{18.015 \mathrm{~g} \mathrm{~mol} \mathrm{H}_{2} \mathrm{O}}=1.74 \mathrm{molH}_{2} \mathrm{O}$,

$\frac{g \mathrm{H}}{\text { Mole } \mathrm{H}_{2} \mathrm{O}}=2.016 \mathrm{~g} \mathrm{H}$

$g \mathrm{H}$ in $100 \mathrm{~g}$ concrete $=1.74 \mathrm{~mol} \mathrm{H}_{2} \mathrm{O} \times 2.016 \mathrm{~g} \mathrm{H}=3.51 \mathrm{~g} \mathrm{H}$,

Volume concrete $=\frac{\text { mass concrete }}{\text { density concrete }}=\frac{100 \mathrm{~g} \text { concrete }}{2.11 \frac{\mathrm{g}}{\mathrm{ml}}}=47.33 \mathrm{ml}$ concrete,

$H$ density $\frac{g}{m l}=\frac{\text { mass } H}{\text { volume concrete }}=\frac{3.51 \mathrm{~g} \mathrm{H}}{47.33 \text { ml concrete }}=7.43 E-02 \frac{\mathrm{g} \mathrm{H}}{\text { ml Concrete }}$.

\subsection{Boron Partial Density}

Subsamples of 8.1.2, 8.2.2, 8.3.2, and 8.4.2 cubes were crushed, dried in an oven to remove moisture, and digested in triplicate using the ASTM method for trace metals analysis in limestone ${ }^{7}$. Three aliquots of sample were weighed in separate beakers and then $10 \mathrm{ml}$ of $\mathrm{HCl}$ and $4 \mathrm{ml}$ of $\mathrm{HNO}_{3}$ were added. The acid mixture was heated at $85^{\circ} \mathrm{C}$ for 60 minutes on a hotplate, with the sample covered with a watch glass. After heating was complete, the sample cooled for an additional 60 minutes to ensure complete boron dissolution. The sample was then diluted up to a final volume of $100 \mathrm{ml}$ with deionized water. The samples were analyzed on the Agilent 730 Inductively Coupled Plasma-Optical Emission Spectrometer (ICP-OES). Boron was calibrated using a High Purity NIST traceable standard (Lot 1204016), Appendix A: Boron Certificate of Analysis. An internal standard (Yttrium) was used to compensate for matrix effects. The dissolution method prescribed in the ASTM method resulted in complete dissolution of the samples. Table 5 is the analytical results of the dissolution of colemanite concrete using the prescribed ASTM method. 
Table 5. Boron Results of Colemanite Concrete Analyzed using ASTM C 1301.

\begin{tabular}{||c|c|c|}
\hline Sample ID & $\begin{array}{c}\text { Average Boron } \\
\text { Content }\end{array}$ & $\begin{array}{c}\text { Partial Boron Density } \\
\left.\mathbf{( g / \mathbf { c m } ^ { 3 }}\right)\end{array}$ \\
\hline 8.1 .2 & $8.12 \mathrm{wt} \%$ & $1.70 \mathrm{E}-01$ \\
\hline 8.2 .2 & $8.14 \mathrm{wt} \%$ & $1.69 \mathrm{E}-01$ \\
\hline 8.3 .2 & $8.37 \mathrm{wt} \%$ & $1.76 \mathrm{E}-01$ \\
\hline 8.4 .2 & $8.07 \mathrm{wt} \%$ & $1.69 \mathrm{E}-01$ \\
\hline
\end{tabular}

Using the calculated colemanite concrete density of $2.09 \mathrm{~g} / \mathrm{cm}^{3}$, the average partial boron density is calculated to be $1.71 \mathrm{E}-01 \mathrm{~g} / \mathrm{cm}^{3}$. For example, the boron density of sample 8.1 .1 in Reference 3 is calculated using the equations:

Mass $\boldsymbol{B}$ in $100 \mathrm{~g}$ concrete from Table $5=8.27 \mathrm{~g}$

Volume concrete $=\frac{\text { mass concrete }}{\text { density concrete }}=\frac{100 \mathrm{~g} \text { concrete }}{2.11 \frac{\mathrm{g}}{\mathrm{ml}}}=47.33 \mathrm{ml}$ concrete

$B$ density $\frac{\mathrm{g}}{\mathrm{ml}}=\frac{\text { mass } B}{\text { volume concrete }}=\frac{8.27 \mathrm{~g} \mathrm{~B}}{47.33 \mathrm{ml} \text { concrete }}=1.75 E-01 \frac{\mathrm{g} \mathrm{B}}{\mathrm{ml \text {Concrete }}}$

\subsection{Conclusions}

The lower limits and measured values for the total density, hydrogen partial density, and boron partial density are presented in Table 6 . The total density, the hydrogen partial density, and the boron partial density exceeded the lower bounds specified in Reference 1.

Table 6. Lower Bounds and Average Measured Values for the Total Density, Hydrogen Partial Density, and Boron Partial Density for the Colemanite Concrete Samples Received 01 August 2012.

\begin{tabular}{|c|c|c|c|c|c|c|}
\hline \multirow{2}{*}{ Material Type } & \multicolumn{2}{|c|}{$\begin{array}{l}\text { Total Density Lower } \\
\text { Bound }\left(\mathrm{g} / \mathrm{cm}^{3}\right)\end{array}$} & \multicolumn{2}{|c|}{$\begin{array}{c}\text { Hydrogen Partial Density } \\
\text { Lower Bound }\left(\mathrm{g} / \mathrm{cm}^{3}\right)\end{array}$} & \multicolumn{2}{|c|}{$\begin{array}{l}\text { Boron Partial Density } \\
\text { Lower Bound }\left(\mathrm{g} / \mathrm{cm}^{3}\right)\end{array}$} \\
\hline & Limit & Measured & Limit & Measured & Limit & Measured \\
\hline $\begin{array}{l}\text { Borated Concrete } \\
\text { (Colemanite) }\end{array}$ & 1.88 & 2.09 & $6.04 \mathrm{E}-02$ & $7.48 \mathrm{E}-02$ & $1.65 \mathrm{E}-01$ & $1.71 \mathrm{E}-01$ \\
\hline
\end{tabular}

\subsection{References}

1 Wead, R., "Radiation Shielding and Fixed Neutron Absorber Panel Material and Inspection Requirements," DCS01-ZMJ-DS-SPE-M-19109-2, Revision 2, (2007).

2 " Equipment Calibration Services / Material Testing," WTA-040-8b, Section 9 (q), 4/13/2012.

${ }^{3}$ Best, D.R., Cozzi, A.D., and Reigel, M.M., "Analytical Results of MOX Colemanite Concrete Sample Poured July 25, 2012 - Cured 7 Days," SRNL-STI-2012-00510, (2012).

4 "Standard Test Method for Density, Absorption, and Voids in Hardened Concrete," ASTM C 642-06.

5 "Standard Test Method for Compositional Analysis by Thermogravimetry," ASTM E 1131-08.

${ }^{6}$ Waclawska, I, Stoch, L, Paulik, J., and Paulik, F., "Thermal Decomposition of Colemanite," Thermochimica Acta, pp. 307-318, [126] (1988).

7 "Major and Trace Elements in Limestone and Lime by Inductively Coupled Plasma-Atomic Emission Spectroscopy (ICP) and Atomic Absorption (AA)," ASTM C 1301-95 (Reapproved 2009). 
SRNL-STI-2012-00543

Revision 0

Appendix A. Boron Certificate of Analysis 


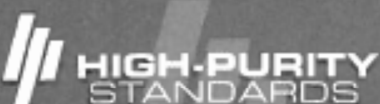 \\ wminighoursyatandards com}

\section{Certifícate of Analysis}

\section{Product Description:}

$\begin{array}{llll}\text { Name: } & \text { Boron } & \text { Source Material: } & \text { Boric Acid } \\ \text { Part Number: } & \mathbf{1 0 0 0 7 - 4} & \text { Material Purity: } & 99.999 \% \\ \text { Lot Number: } & \mathbf{1 2 0 4 0 1 6} & \text { Matrix: } & \mathrm{H}_{2} \mathrm{O}\end{array}$

\section{Certified Value:}

$1000 \mu \mathrm{g} / \mathrm{mL} \pm 3 \mu \mathrm{g} / \mathrm{mL}$

The Certified value is based on gravimetric and volumetric preparation, and confirmed against SRM 3107 (lot number 070514) by inductively coupled plasma optical emission spectrometry (ICP-OES) using an internal laboratory-developed method. The uncertainty in the certified value is calculated for a $95 \%$ confidence interval and coverage factor $k$ is about 2 .

Density:

$$
1.000 \mathrm{~g} / \mathrm{mL} \pm 0.002 \mathrm{~g} / \mathrm{mL} @ 22.8^{\circ} \mathrm{C}
$$

Uncertified Values:

Titration Value:

$$
994.97 \mu \mathrm{g} / \mathrm{mL}
$$

Trace Metal Impurity Scan: The data reported are based upon a scan of this specific lot at $1000 \mu \mathrm{g} / \mathrm{mL}$ via

\begin{tabular}{|c|c|c|c|c|c|c|c|c|c|c|c|c|c|}
\hline $\mathrm{Ag}$ & 0.02 & $\mathrm{Cu}$ & $<$ & 0.1 & $\mathbf{L i}$ & $<$ & 1 & $\mathbf{R b}$ & $<$ & $0.0 ?$ & Th & $<$ & 0.02 \\
\hline Al & 0.1 & Dy & $<$ & 0.02 & $\mathbf{L u}$ & $<$ & 0.02 & Re & $<$ & 0.02 & $\mathrm{~T}$ & $<$ & 0.02 \\
\hline As & 0.05 & Er & $<$ & 0.02 & $\mathrm{Mg}$ & $<$ & 0.5 & $\mathbf{R h}$ & $<$ & 0.02 & $\mathrm{TI}$ & $<$ & 0.02 \\
\hline $\mathrm{Au}$ & 0.02 & $\mathrm{Eu}$ & $<$ & 0.02 & $\mathrm{Mn}$ & $<$ & 0.5 & $\mathbf{R u}$ & $<$ & 0.02 & $\mathrm{Tm}$ & $<$ & 0.02 \\
\hline B & $M$ & $\mathrm{Fe}$ & $<$ & 5 & Mo & $<$ & 0.02 & Sb & $<$ & 0.02 & $\mathrm{U}$ & $<$ & 0.1 \\
\hline $\mathrm{Ba}$ & 0.1 & $\mathrm{Ga}$ & $<$ & 0.02 & $\mathrm{Na}$ & $<$ & 10 & Se & $<$ & 0.02 & V & $<$ & 0.05 \\
\hline $\mathrm{Be}$ & 0.02 & Gd & $<$ & 0.02 & $\mathrm{Nb}$ & $<$ & 0.02 & Se & $<$ & 0.1 & w & $<$ & 0.02 \\
\hline $\mathrm{Bi}$ & 0.02 & $\mathrm{Ge}$ & $<$ & 0.02 & $\mathrm{Nd}$ & $<$ & 0.02 & Si & $<$ & 5 & $\mathbf{Y}$ & $<$ & 0.02 \\
\hline $\mathrm{Ca}$ & $<$ & $\mathrm{H} \mathscr{f}$ & $<$ & 0.02 & $\mathrm{Ni}$ & $<$ & 0.02 & Sm & $<$ & 0.02 & $\mathrm{Yb}$ & $<$ & 0.02 \\
\hline $\mathrm{Cd}$ & 0.02 & Ho & $<$ & 0.02 & Os & $<$ & 0.02 & Sn & $<$ & 1 & $\mathrm{Zn}$ & $<$ & 0.1 \\
\hline $\mathrm{Ce}$ & 0.02 & In & $<$ & 0.02 & $\mathrm{~Pb}$ & $<$ & 0.05 & $\mathrm{Sr}$ & $<$ & 0.02 & $\mathrm{Zr}$ & $<$ & 0.02 \\
\hline Co & 0.05 & Ir & $<$ & 0.02 & Pd & $<$ & 0.02 & $\mathrm{Ta}$ & $<$ & 0.02 & & & \\
\hline $\mathrm{Cr}$ & 0.1 & $\mathbf{K}$ & $<$ & 1 & $\mathrm{Pt}$ & $<$ & 0.02 & $\mathrm{~Tb}$ & $<$ & 0.02 & & & \\
\hline Cs & $<\quad 0.02$ & La & $<$ & 0.02 & $\mathrm{Pt}$ & $<$ & 0.02 & $\mathrm{Te}$ & $<$ & 0.02 & & & \\
\hline
\end{tabular}
ICP analysis. The values are reported in $\mu \mathrm{g} / \mathrm{L}$.

Preparation Information:

The standard solution is prepared using high purity materials and assayed by analytical methods for conformity prior to use. This standard was prepared using the methods developed at NIST for SRM Spectrometric Standard Solutions under appropriate laboratory conditions.

The matrix is 18 megaohm deionized water.

Stability of this product is based upon rigorous short term and long term testing of the solution for the certified value. This testing includes, but is not limited to, the effect of temperature and packaging on the product.

Intended Use:

This Certified Reference Material (CRM) is intended for use as a calibration standard for the quantitative determination of boron, calibration of instruments such as ICPOES, ICPMS, AAS and XRF, and validation of analytical methods. It also can be used in EPA, ASTM and other methods. 
SRNL-STI-2012-00543

Revision 0

Traceability Information:

The traceability of this standard is maintained through an unbroken chain of comparisons to appropriate standards with suitable procedure and measurement uncertainties. The maintenance of the base and derived units of International System of Units (SI) with traceability of measurement results (contemporary metrology)

to SI ensures their comparability over time as follows.

a. Standard Weight and Analytical Balance

The standard weights (NBS weights Inventory No 20231A) are calibrated every two years by South Carolina Metrology Laboratory that is a participant in "NIST Weights and Measures Measurement Assarance Program" with a certificate of measurement traceability to NIST primary standards.

The balances are calibrated yearly by the ISO 17025 accredited metrology service, and are verified weekly by an in-house method using standard weights.

b. Volumetric Device

The calibration of volumetric vessels is checked annually using the NBS 602 method.

c. Thermometer

The standard thermometers are calibrated every year by the ISO 17025 accredited metrology service. The thermometers used in-house are verified against the standard thermometers yearly.

d. Calibration Standards:

The Calibration Standard is directly traceable to SRM 3100 Series Spectrometric Standard Solutions.

Packaging and Storage Conditions:

The standard is packaged in a pre-cleaned polyethylene bottle. To maintain the integrity of this product, the solution should be kept tightly capped and stored under normal laboratory conditions.

Refer to Material Safety Datasheet (MSDS) for hazardous information.

Expiration Information:

The expiry date is guaranteed to be valid for eighteen months from the shipping date provided. For this reason, standards from the same lot may have differeat expiration dates.

$\begin{array}{ll}\text { Preparation Date: } & \text { February 9,2012 } \\ \text { Shipped Date: } & \text { MAR } 092012 \\ \text { Expiration Date: } & \text { SEP } 092013\end{array}$

Expiration Date:

February 29, 2012

Quality Information:

(ACLASS

1SO/IEC 17025:2005 Aecreditation Certifleate Number AT-1529
(ACLASS

ISO Guide 34:2009 (RMP) Accreditation

Certifieate Number AR-1436

$$
\text { Coing } 1 \text {. }
$$

Vanny T. Yib,

Inorganic Laboratory Manager

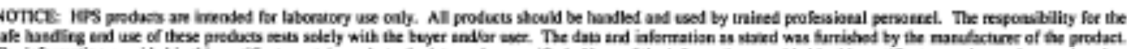

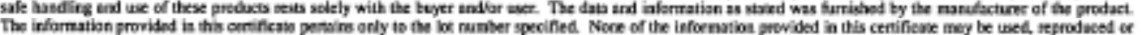

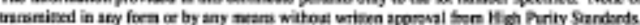




\section{Distribution:}

D.R. Best, 999-W

S. D. Fink, 773-A

K.M. Fox, 999-W

B. J. Giddings, 786-5A

C. C. Herman, 999-W

S. L. Marra, 773-A

F. M. Pennebaker, 773-42A

B.R. Pickenheim, 999-W

M.M. Reigel, 999-W

J.A. Spear, 235-11F

J. P. Vaughan, 773-41A 